DOI: https://doi.org/10.32838/2523-4803/70-3-26

удК 336:65.016.8

\title{
Кащена Н.Б.
}

кандидат економічних наук, доцент,

Харківський державний університет харчування та торгівлі

\section{Kashchena Nataliia}

Kharkiv State University of Food Technology and Trade

\section{МЕХАНІЗМ УПРАВЛІННЯ ЕКОНОМІЧНОЮ АКТИВНІСТЮ ПІДПРИЕМСТВ ТОРГІВЛІ}

У статті обтрунтовано теоретико-методичні засади формування механізму управління економічною активністю підприємств торгівлі. Доведено, щчо механізм є рушійною силою управління $і$ як самостійний елемент системи управління економічною активністю являє собою оптимальну сукупність взаємопов 'язаних форм, структур, методів, важелів та інструментів, щзо забезпечують своєчасне регулювання напрямів управлінських впливів, реалізація яких орієнтована на досягнення иільових параметрів розвитку економічної активності. Розроблено функиіональну модель механізму управління економічною активністю підприємств торгівлі, яка, на відміну від існуючих, інтегрує визначені структурні елементи механізму у чотирьох комплексних блоках (складниках), через взаємозв'язок $i$ взаємозалежність реалізаиії яких забезпечується результативність прийнятих управлінських рішень у сфері розвитку економічної активності.

Ключові слова: підприємство торгівлі, економічна активність, управління, механізм, формування.

Постановка проблеми. Роздрібна торгівля відіграє значну роль у задоволенні потреб споживачів у високоякісних товарах і послугах та у формуванні економічного потенціалу України. За даними Державної служби статистики, минулого року оборот роздрібної торгівлі зріс на 10,5\%. Це підвищення вперше за останні шість років випереджало зростання інфляції і, за прогнозами, у цьому році мало посилюватися. За січень-березень 2020 року обсяги роздрібної торгівлі в Україні зросли майже на 18\% порівняно 3 аналогічним періодом 2019 року [7]. Проте карантин, пов'язаний з COVID19, паралізував більшу частину роздрібної торгівлі (майже 2 місяці не працюють ТРЦ, ринки і практично всі магазини, що продають непродовольчі товари). На відновлення колишніх обсягів торгівлі, за свідченням директора Української торгової гільдії Є. Локтіонової, знадобиться не менше 12 місяців 3 моменту послаблення карантинних обмежень [5]. Зважаючи на це, вкрай важливим для ритейрелів $є$ питання виживання в складній економічній ситуації, результативного функціонування та розвитку. Оскільки економічна ефективність діяльності підприємств роздрібної торгівлі багато в чому залежить від рішень, що генеруються менеджментом у сфері їхньої економічної активності, набуває актуальності питання розроблення такого механізму управління економічною активністю підприємств торгівлі, який би створив сприятливі умови для ефективного функціонування і забезпечив конкурентні переваги високого порядку.

Аналіз останніх досліджень і публікацій. Інструментальна підтримка управління діяльністю суб'єктів підприємницької діяльності $€$ предметом пильної уваги сучасних вітчизняних і зарубіжних науковців. Актуальні проблеми теорії та практики розроблення, структуризації та ефективного функціонування механізмів управління діяльністю торговельних підприємств в контексті забезпечення їхньої конкурентоспроможності, економічної та фінансової стійкості, результативного функціонування та розвитку розглядали в своїх працях Т.Г. Васильців, О.В. Гегера [4], Н.І. Дуляба, С.К. Золотарьов [1], Г.І. Івасів, П. О. Куцик [4], Н. В. Магас, Є.І. Масленніков [6], Н.Г. Міценко, О.В. Побережець, М.Є. Рогоза, I.А. Сененко, В.О. Соболєв, О.О. Тараненко,Т.В. Футало та ін. Проте через різноплановість механізмів (організаційний, економічний, фінансовий, фінансово-економічний тощо), важелів, методів, об'єктів та інструментів управлінського впливу ідентифікація механізму управління економічною активністю підприємств торгівлі та його складників залишається дискусійним питанням і потребує подальшого розвитку.

Формулювання цілей статті. Метою статті $\epsilon$ обгрунтування теоретико-методичних засад формування механізму управління економічною активністю підприємств торгівлі.

Виклад основного матеріалу. Безпечність та ефективна робота підприємств торгівлі, імідж у діловому співробітництві та перспективи сталого розвитку значною мірою зумовлюються інструментальним аспектом забезпечення управління економічною активністю кожного з них. Загалом управління економічною активністю підприємств торгівлі спрямовано на забез- 
печення ефективності та результативності економічної діяльності в умовах динамічних змін бізнес-середовища та потреб стейкхолдерів.

3 позиції процесного підходу управління економічною активністю підприємств торгівлі слід розглядати як послідовне виконання певних управлінських функцій, спрямованих на досягнення поставлених цілей [2, с. 130]. Реалізація функцій управління у їх взаємозв'язку та взаємообумовленості відтворює циклічність управлінського процесу (рис. 1) і забезпечується відповідним функціональним механізмом.

Механізм управління економічною активністю підприємств торгівлі є рушійною частиною системи управління, складається 3 певних елементів і забезпечує дієвий вплив на фактори, стан яких обумовлює результати їх функціонування. Його слід формувати 3 урахуванням загальних закономірностей розвитку ринку (високий динамізм, локальний характер і територіальна сегментація ринку товарів і послуг тощо), особливостей діяльності торговельних підприємств (переважання малих і середніх підприємств в структурі галузі та висока швидкість обороту капіталу; велика чутливість до ринкової інфраструктури; динамічність бізнес-моделей і структур управління тощо) та низки внутрішніх факторів, здатних вплинути на його ефективність:
1) організаційно-управлінських (рівень ефективності організації управління; стабільність внутрішньої організаційної структури управління та взаємодії між відділами та службами підприємства; рівень фінансово-економічного менеджменту; застосування новітніх бізнес-моделей і технологій управління торговельною діяльністю; рівень використання інновацій тощо);

2) фінансово-економічних (рівень забезпеченості фінансово-економічними ресурсами; оптимальність складу і структури активів підприємства та джерел їх утворення; рівень рівноваги активів і капіталу підприємства; кредитоспроможність підприємства і оптимізація кредитної політики; раціональність використання фінансово-ресурсного потенціалу підприємства; відповідність капітальних вкладень приросту прибутку і довготермінових пасивів тощо);

3) кадрово-соціальних (кадрове забезпечення діяльності та структура персоналу; умови праці та рівень матеріального добробуту працівників; рівень організації і мотивації праці; розвиненість соціальної інфраструктури та соціального захисту; навчання і підвищення кваліфікації кадрів тощо).

Враховуючи стратегічну спрямованість управління економічною активністю підприємств торгівлі, механізм цього процесу орієнтований на досягнення цільових параметрів іiі розвитку (підвищення ефек-

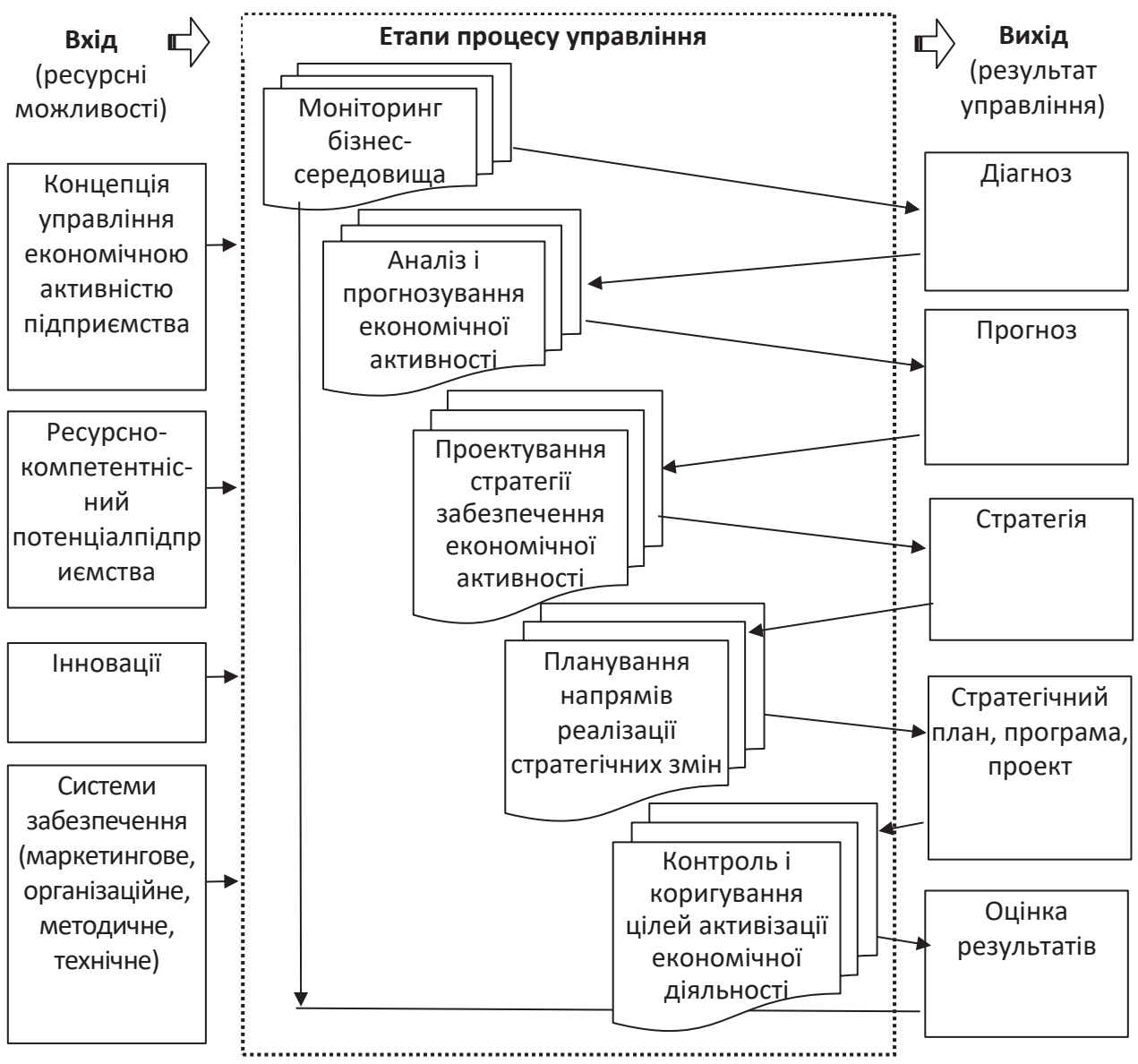

Рис. 1. Референтна модель процесу управління економічною активністю підприємства ритейлу 
тивності господарювання, оптимізація бізнес-процесів, зміцнення життєздатності, економічне зростання тощо) в умовах динамічних змін бізнес-середовища і потреб стейкхолдерів, позитивну динаміку результативних показників та стійкі конкурентні позиції на ринку. Як і будь-який інший, механізм управління економічною активністю вбудований у загальну систему управління торговельним підприємством. Він $€$ одночасно елементом матеріальної складової частини ресурсного забезпечення процесу управління та самостійною системою, яка:

- інтегрує сукупність методів, важелів, інструментів, ресурсів і способів їх поєднання для забезпечення найбільш ефективної реалізації процесних функцій управління (аналіз, планування, організація, мотивація, контроль, регулювання тощо);

- визначає вплив суб'єктів (власники, керівники підприємства та його підрозділів, інші зацікавлені особи) на об'єкт (ресурси і результати діяльності підприємства тощо) у всіх сферах економічної діяльності (кадри, інформація, матеріали, фінанси, інвестиції, інновації, маркетинг, збут тощо);

- грунтується на методологічних підходах та принципах управління економічною діяльністю підприємств;

- забезпечує максимальну адаптацію до сучасних умов функціонування та оперативне коригування засобів досягнення відповідності фактичних параметрів економічної активності підприємства заданим стратегічним орієнтирам.

Метою такої системи є створення умов для досягнення запланованого рівня розвитку економічної активності торговельного підприємства. Її реалізація передбачає конкретизацію цілей і завдань меха- нізму управління відповідно до вибраної стратегії розвитку підприємства. «Кожне завдання повинно містити кількісну характеристику кінцевого результату та критерії його досягнення. Завдання мають бути зрозумілими їх виконавцям і збігатися з їхніми інтересами, тобто відбивати соціальну спрямованість управління. Кожне завдання супроводжується низкою заходів щодо його реалізації, а кожен захід, у свою чергу, є комбінацією методів і засобів управління, що взаємопов'язані спільністю однієї мети, за допомогою яких реалізується спрямованість і конкретні параметри управлінських дій. Застосування ж методів і засобів управління потребує наявності всіх основних функцій управління» [3, с. 41]. Реалізація цілей і завдань механізму управління економічною активністю торговельного підприємства сприяє досягненню запланованих результатів.

Задля забезпечення ефективності механізму управління економічною активністю підприємств торгівлі його слід формувати із дотриманням низки принципів (табл. 1) і визначенням основних структурних ланок управління:

- форм організації трудової діяльності (поділ праці, спеціалізація тощо), за рахунок вдосконалення яких забезпечується можливість впливу на розвиток компетенцій та підвищення ефективності використання персоналу підприємства;

- структур, форм і методів планування та менеджменту, у складі яких поряд 3 економічними можуть бути виділені правові, соціально-психологічні та інші форми і методи;

- сукупності економічних важелів та стимулів впливу на діяльність підприємства і його контрагентів, за допомогою яких забезпечується узгодження еконо-

Таблиця 1

Принципи формування механізму управління економічною активністю підприємств торгівлі

\begin{tabular}{|c|c|c|}
\hline № 3/II & Принцип & Характеристика принципу \\
\hline 1. & $\begin{array}{l}\text { стратегічність та } \\
\text { підпорядкованість }\end{array}$ & $\begin{array}{l}\text { розроблення механізму управління економічною активністю в інтеграції з головною } \\
\text { стратегією розвитку торговельного підприємства }\end{array}$ \\
\hline 2. & цільова спрямованість & $\begin{array}{l}\text { орієнтація на стратегічні та тактичні цілі розвитку економічної активності, їх } \\
\text { узгодженість із стратегічними цілями розвитку підприємства та забезпечення бажаних } \\
\text { кінцевих результатів }\end{array}$ \\
\hline 3. & планомірність & $\begin{array}{l}\text { координація всіх планів підприємства і врахування цільових завдань економічної } \\
\text { активності, залучення у ці процеси різних служб підприємства. }\end{array}$ \\
\hline 4. & безперервність & $\begin{array}{l}\text { забезпечення життєздатності та розвитку економічної активності підприємства на } \\
\text { постійній основі }\end{array}$ \\
\hline 5. & $\begin{array}{l}\text { своєчасність та } \\
\text { адаптивність }\end{array}$ & $\begin{array}{l}\text { негайна реакція системи забезпечення економічної активності підприємства на } \\
\text { виникаючі небезпеки, загрози і ризики та запровадження заходів із недопущення їх } \\
\text { негативного впливу }\end{array}$ \\
\hline 6. & науковість & $\begin{array}{l}\text { дотримання вимог об’єктивних економічних законів, урахування реальних умов } \\
\text { функціонування та особливостей інформаційної економіки, що зумовлюють } \\
\text { необхідність нововведень }\end{array}$ \\
\hline 7. & обгрунтованість & $\begin{array}{l}\text { логічне обгрунтування та перевірка на практиці. форми, структури, методів та заходів } \\
\text { управління, що визначають склад і внутрішню будову механізму управління }\end{array}$ \\
\hline 8. & оптимальність & $\begin{array}{l}\text { вибір варіанту розвитку економічної активності, який при наявних ресурсах забезпечить } \\
\text { максимальне задоволення інтересів підприємства та стейкхолдерів }\end{array}$ \\
\hline 9. & $\begin{array}{l}\text { комплексність } \\
\text { функціонування та } \\
\text { розвитку }\end{array}$ & єдність засобів впливу як у просторі, так і в часі \\
\hline
\end{tabular}


мічних інтересів стейкхолдерів і зростання економічної активності підприємств торгівлі.

Дотримання зазначених принципів формування i структурування механізму управління економічною активністю підприємств торгівлі здійснюється через відповідні управлінські функції, кожна $з$ яких наближає до досягнення стратегічної мети активізації економічної діяльності торговельного підприємства. Ефективне виконання управлінських функцій забезпечується певним інструментарієм. Останній являє собою сукупність методів, важелів і способів здійснення управлінського впливу на економічну діяльність у процесі досягнення поставленої мети, а також засобів їх реалізації. Їх інтеграція дає змогу визначити кроки, які потрібно здійснити, щоб виконати певні завдання для досягнення цільових параметрів економічної активності та їх зміни в контексті забезпечення сталого розвитку, що у своїй сукупності сприятимуть досягненню поставлених стратегічних цілей економічного зростання. Інструментальний портфель механізму управління економічною активністю підприємств торгівлі становлять певні методи, важелі та засоби. Серед основних методів слід назвати:

- економічні - забезпечують формування умов для ефективної діяльності підприємства, оцінки ії результативності з урахуванням потенційних ризиків і загроз, прогнозування i контролювання рівня економічної активності підприємства. До них відносяться методи планування (ресурсний, цільовий, нормативний, балансовий, матричний тощо), аналізу (горизонтальний, вертикальний, трендовий, порівняльний, факторний, фінансових коефіцієнтів), контролю (відповідності фактичних показників плановим, аналіз витрат за центрами обліку та звітності, аналіз цінності капіталу, визначення показників економічної активності за підрозділами тощо) та прогнозування (економетричні, регресійні, Бокса-Дженкінса та ін);

- соціально-психологічні - забезпечують вплив на процеси, пов'язані з урегулюванням проблем із трудовим колективом, які призводять до зниження рівня економічної активності підприємства;

- адміністративні - забезпечують організацію, реалізацію та регуляцію управлінських функцій у контексті досягнення високого рівня економічної активності підприємства;

- правові - забезпечують правове регулювання відносин між працівниками та менеджерами, захист прав і законних інтересів підприємства та його персоналу задля формування правового базису підвищення рівня економічної активності підприємства шляхом урегулювання.

Поряд із методами важливим складником інструментального портфеля забезпечення економічної активності торговельного підприємства $є$ важелі та засоби, за допомогою яких здійснюється вплив з метою отримання бажаного результату. Останні можуть бути технічними, економічними, правовими, інформаційними, політичними тощо i, відповідно, пов'язані із прийняттям управлінських рішень на користь підприємства в тій чи іншій сфері його діяльності.

Стабільне функціонування механізму управління економічною активністю підприємств торгівлі потребує відповідного системного забезпечення управлінського процесу. Саме тому обов'язковими складниками такого механізму є:

- нормативно-правове забезпечення (внесення змін до наявних або розроблення нових нормативноправових актів, що стосуються цієї сфери);

- організаційне забезпечення (активна співпраця всіх функціональних структур підприємства);

- фінансово-економічне забезпечення (підвищення ресурсних можливостей підприємства, забезпечення збалансованості доходів і витрат тощо);

- кадрове забезпечення (створення навчальної бази підготовки, перепідготовки і підвищення кваліфікації працівників для формування ефективної системи управління економічною активністю);

- інноваційне забезпечення (формування центрів 3 інноваційної підтримки процесів розроблення та реалізації стратегії розвитку економічної активності);

- інформаційно-аналітичне забезпечення (формування інформаційних систем моніторингу показників економічної активності підприємства).

Однією з умов ефективної реалізації механізму управління економічною активністю підприємств торгівлі є наявність системи оцінювання ступеня досягнення кінцевої мети та інших (проміжних) цілей господарювання у довгостроковій перспективі. По суті це система показників, яка дає змогу всебічно оцінити результативність використання задіяних задля досягнення цільових параметрів фінансово-економічних ресурсів та шляхом аналітичної інтерпретації результатів, отриманих під час контролю і поточного моніторингу, ідентифікувати рівень економічної активності підприємства, визначити тенденції його зміни та забезпечити можливість прогнозування. Базою для іiі формування може бути загальновідома класична система збалансованих показників, адаптована під потреби різних рівнів управління економічною активністю підприємств торгівлі шляхом іiі розширення інтегральними, локальними та частковими показниками складників активності економічної діяльності. Це забезпечує значний ступінь деталізації оцінки, можливість комплексної фундаментальної діагностики та наукового обгрунтування заходів із залучення виявлених резервів підвищення економічної активності.

Вище обгрунтовані теоретико-методичні засади формування механізму управління економічною активністю торговельного підприємства покладено в основу розроблення його функціональної моделі, принциповою відмінністю якої $є$ інтеграція визначених структурних елементів механізму у цільових комплексних блоках (складниках), через взаємозв'язок і взаємозалежність реалізації яких забезпечується результативність прийнятих управлінських рішень у сфері розвитку економічної активності (рис. 2). 


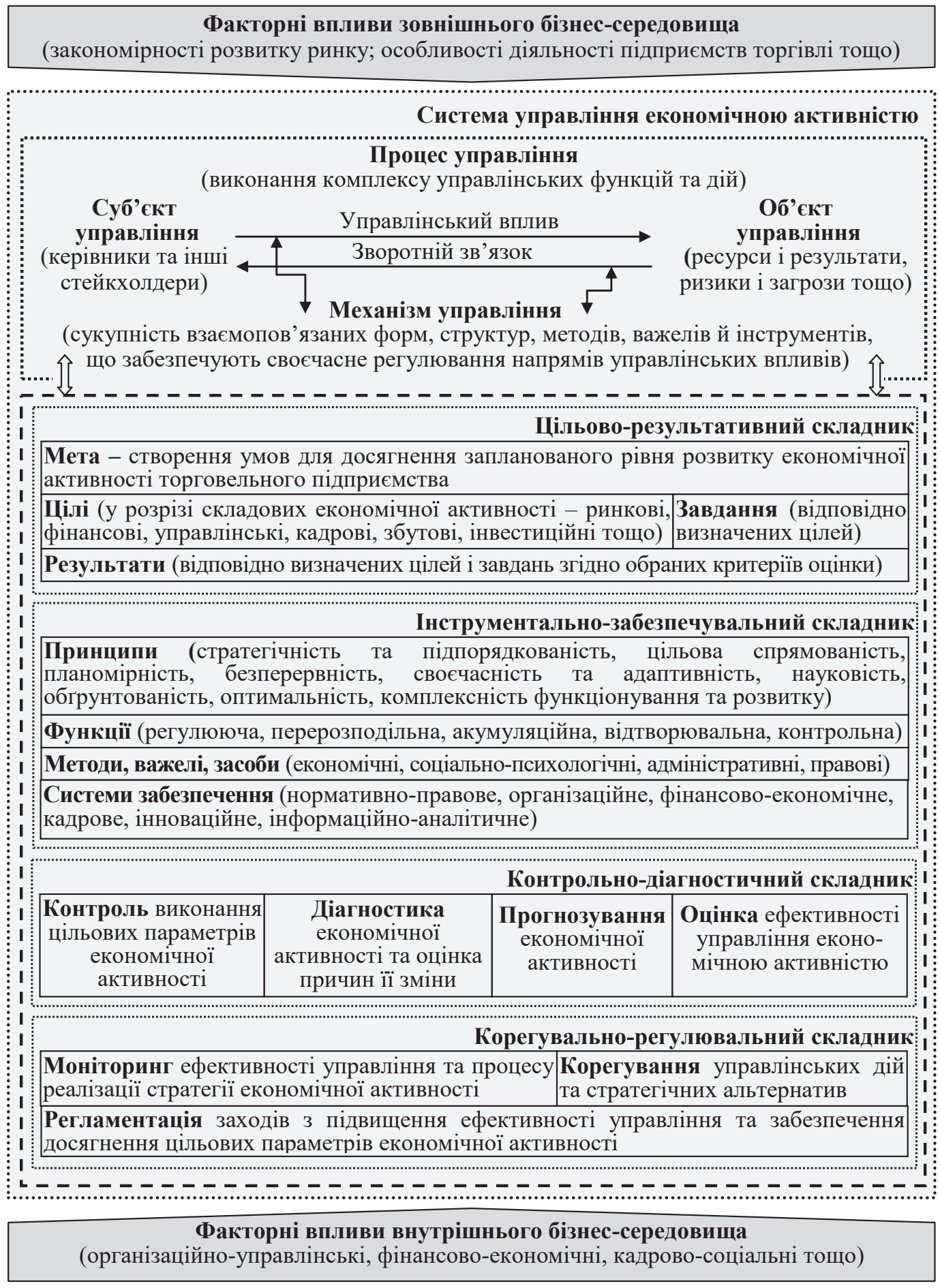

Рис. 2. Функціональна модель механізму управління економічною активністю підприємств торгівлі

Архітектоніку розробленої функціональної моделі механізму управління економічною активністю підприємств торгівлі представлено чотирма складниками:

- цільово-результативний (визначає мету, цілі і завдання механізму управління економічною активністю підприємств торгівлі, а також очікувані результати його дії загалом і у розрізі окремих складників економічної активності);
- інструментально-забезпечувальний (ідентифікує принципи, функції, методи, важелі та інструменти механізму управління економічною активністю, а також його організаційне, нормативно-правове, інформаційно-аналітичне, кадрове, фінансово-економічне, програмне та інноваційне забезпечення);

- контрольно-діагностичний (орієнтований на здійснення контролю виконання цільових параметрів економічної активності, діагностику причин їх змін і 
прогнозування подальшого розвитку, а також оцінку ефективності управління економічною активністю підприємства та моніторинг);

- корегувально-регулювальний (спрямований на моніторинг ефективності управління та реалізації стратегії економічної активності підприємства, їі коригування (за необхідності) та регламентацію заходів 3 усунення виявлених відхилень, збоїв, недоліків тощо).

Їх інтеграція забезпечує ефективне формування i реалізацію механізму управління економічною активністю підприємств торгівлі, а також потужну інструментальну підтримку досягнення цільових параметрів розвитку економічної активності, адаптивність та своєчасне реагування на зміни умов бізнес-середовища та уподобань споживачів.

Висновки. Дослідження теоретико-методичних засад формування механізму управління економічною активністю підприємств торгівлі виявило, що його можна розглядати як складник загальної системи управління і як самостійну систему. Як самостійна система механізм управління економічною активністю являє собою оптимальну сукупність взаємопов'язаних форм, структур, методів, важелів та інструментів, що забезпечують своєчасне регулювання напрямів управлінських впливів, реалізація яких орієнтована на досягнення цільових параметрів іiі розвитку. Архітектоніка розробленої функціональної моделі механізму управління економічною активністю представлена цільово-результативним, інструментально-забезпечувальним, контрольно-діагностичним i корегувально-регулювальнним складниками, інтеграція яких забезпечує його ефективність. Ефективний механізм управління економічною активністю підприємств торгівлі забезпечує досягнення стратегічних цілей іï розвитку, створення продуктивної системи мотивації діяльності персоналу, ухвалення конструктивних управлінських рішень, адаптивність до динамічних змін бізнес-середовища і потреб стейкхолдерів, повноту та збалансованість функціонування усіх структурних підрозділів і підсистем забезпечення. Перспектива подальших наукових пошуків полягає у моделюванні та розбудові композиційних складників механізму управління економічною активністю торговельного підприємства.

\section{Список літератури:}

1. Золотарьов С.К., Шило Ю.М. Методичні підходи до формування соціально-економічного механізму управління торговельним підприємством. Причорноморські економічні студї. 2016. Вип. 11. С. 195-198.

2. Кащена Н.Б. Моделювання процесу стратегічного управління економічною активністю торговельного підприємства. Інфраструктура ринку. 2019. Вип. 34. С. 125-134. DOI: https://doi.org/10.32843/infrastruct34-18

3. Куценко А.В. Організаційно-економічний механізм управління ефективністю діяльності підприємств споживчої кооперації України: монографія. Полтава: РВВ ПУСКУ, 2008. 205 с.

4. Куцик П.О., Герега О.В. Організаційно-економічний механізм управління ефективною діяльністю підприємств торгівлі: теоретичний аспект. Держава та регіони. 2018. № 3 (102). С. 99-104.

5. Локтіонова С. За позитивного сценарію кризи торгівля може скоротитися на 40\%, за негативного на всі 70\%. URL: https://nv.ua/ukr/biz/consmarket/koronavirus-i-riteyl-torgivlya-mozhe-skorotitisya-do-70-novini-ukrajini50077465.html (дата звернення: 12.05.2020).

6. Масленніков С. І. Формування механізму управління фінансовою стійкістю торговельного підприємства. Ринкова економіка: сучасна теорія і практика управління. 2017. Том 16. Вип. 2 (36). С. 53-69.

7. Оптовий та роздрібний товарооборот підприємств оптової та роздрібної торгівлі. URL: http://www.ukrstat.gov.ua/operativ/menu/menu_u/sze.htm (дата звернення: 12.05.2020).

\section{References:}

1. Zolotarev S.K., Shilo Yu.M. (2016). Metody`chni pidxody` do formuvannya social`no-ekonomichnogo mexanizmu upravlinnya torgovel'ny'm pidpry`yemstvom [Methodical approaches to the formation of socio-economic mechanism of trade enterprise management]. Black Sea Economic Studies, vol. 11, pp. 195-198.

2. Kashchena N. B. (2019) Modelyuvannya procesu strategichnogo upravlinnya ekonomichnoyu akty`vnistyu torgovel'nogo pidpry`yemstva [Modelling of the process of strategic management of economic activity of a trading enterprise]. Market Infrastructure. vol. 34, pp. 125-134. DOI: https://doi.org/10.32843/infrastruct34-18

3. Kutsenko A.V. (2008) Organizacijno-ekonomichny’j mexanizm upravlinnya efekty`vnistyu diyal`nosti pidpry`yemstv spozhy`vchoyi kooperaciyi Ukrayiny`: monografiya [Organizational and economic mechanism of management of efficiency of activity of the enterprises of consumer cooperation of Ukraine: monograph]. Poltava: RVV PUSKU, 2008. 205 p.

4. Kutsik P.O., Gerega O.V. (2018) Organizacijno-ekonomichny`j mexanizm upravlinnya efekty`vnoyu diyal ’nistyu pidpry`yemstv torgivli: teorety`chny`j aspekt [Organizational and economic mechanism of management of effective activity of trade enterprises: theoretical aspect]. State and regions, no 3 (102), pp. 99-104.

5. Loktionova $\mathrm{E}$. In the positive scenario of the crisis, trade may decline by $40 \%$, in the negative by all $70 \%$. Available at: https://nv.ua/ukr/biz/consmarket/koronavirus-i-riteyl-torgivlya-mozhe-skorotitisya-do-70-novini-ukrajini-50077465. html (access date: 12.05.2020). 
6. Maslennikov E.I. (2017) Formuvannya mexanizmu upravlinnya finansovoyu stijkistyu torgovel'nogo pidpry'yemstva [Formation of a mechanism for managing the financial stability of a commercial enterprise]. Market Economy: Modern Management Theory and Practice, 2017. part. 16, vol. 2 (36), pp. 53-69.

7. Wholesale and retail turnover of wholesale and retail trade. Available at: http://www.ukrstat.gov.ua/operativ/menu/ menu_u/sze.htm (access date: 12.05.2020).

\section{МЕХАНІЗМ УПРАВЛІННЯ ЕКОНОМІЧНОЮ АКТИВНІСТЮ ПІДПРИЕМСТВ ТОРГІВЛІ}

В статье обоснованы теоретико-методические основы формирования механизма управления экономической активностью предприятий торговли. Доказано, что механизм является движущей силой управления и как самостоятельный элемент системь управления экономической активностью представляет собой оптимальную совокупность взаимосвязанных форм, структур, методов, рычагов и инструментов, обеспечивающих своевременное регулирование управленческих воздействий, ориентированных на достижение иелевых параметров развития экономической активности. Разработана функциональная модель механизма управления экономической активностью предприятий торговли, которая интегрирует выделенные структурные элементы механизма 6 четырех комплексных блоках, взаимосвязь и взаимозависимость которых обеспечивает результативность реализачии принимаемых управленческих решений в сфере развития экономической активности.

Ключевые слова: предприятие торговли, экономическая активность, управление, механизм, формирование.

\section{THE MECHANISM OF MANAGEMENT OF THE ECONOMIC ACTIVITY OF TRADE ENTERPRISES}

The article substantiates the theoretical and methodological principles of forming a mechanism of management of the economic activity of trade enterprises. It is noted that in today's difficult economic situation, it is extremely important for domestic retailers to develop an effective mechanism capable of ensuring efficient operation and high-order competitive advantages. It is proved that the mechanism of management of the economic activity is the driving force of the management process and a component of the management system of a trade enterprise. It is proposed to define this mechanism as an optimal set of interconnected forms, structures, methods, levers and tools that provide timely regulation of areas of managerial influence, the implementation of which is focused on achieving the target parameters of economic activity. The components of the mechanism of management of the economic activity of trade enterprises (the purpose, principles, functions, tool structure in the form of methods, levers, means), a providing basis, functions and directions of administrative influence are defined. The external and internal factors of the business environment are identified, the influence of which determines the formation of the results of the management process and determines the effectiveness of its tool support. A functional model of the mechanism of management of the economic activity of trade enterprises is developed, which, unlike the existing ones, integrates certain structural elements of the mechanism in four complex blocks (target and effective, tools supportive, control and diagnostic, corrective and regulatory), through interconnection and interdependence of their realization effectiveness of the implementation of management decisions in the field of economic activity, control of their implementation and timely adjustment are ensured. The use of the proposed model in the practice of trade enterprises will provide effective formation and powerful tools support for achieving the target parameters of economic activity, adaptability and timely response to changes in the business environment and consumer preferences. The development of the composite components of the mechanism of management of the economic activity of the trade enterprise is considered promising.

Key words: trade enterprise, economic activity, management, mechanism, formation. 